高分子耣文集 (Kobunshi Ronbunshu), Vol. 41, No. 12, pp. 733-738 (Dec., 1984)

\title{
ポリエチレンとエチレンープロピレン共重合体の 放射線酸化による酸莱の消費と酸化領域
}

\author{
荒川 和夫*1・瀬口 忠男*1
}

(受付 1984 年 4 月 27 日・藉查終了 1984 年 7 月 14 日)

\begin{abstract}
要 旨 ポリエチレン (PE) 及びエチレンープロピレン共重合体 (EPR) を放射線酸化したときの酸

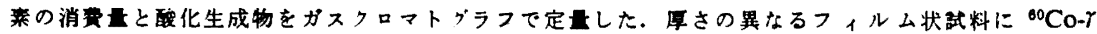

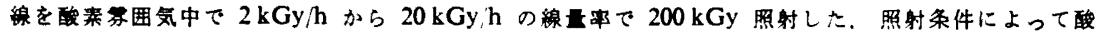
化はフィルム内で不均一になり，酸秦の消费量のG值はフィルムが厚くなるほと，また線率が高く

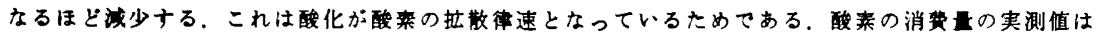
拉散モデル用いた計算值と一致し，フィルムの酸化届の厚さは線量率のー-1/3 乘に比例ナることが 示された.
\end{abstract}

\section{1 緒}

高分子は放射線照射によって，分子鎖間の橋かけや高 分子主鎖及び㑡鎖の切断を生じ，多種類の気体を発生す ろ. 発生する気体の種類と量は高分子の種類や照射雾囲 気によって異なる．酸素雾囲気中で高分子を照射すると 故射線酸化を伴い，酸化生成物である $\mathrm{CO}, \mathrm{CO}_{2}, \mathrm{H}_{2} \mathrm{O}$ などのガスが発生する1). 酸化が共存すると一般に材料 としての損鹪が著しくなる．したがって空気中を含め て, 酸素存在下で使用される高分子材料の酎放射線性を 評価するためには，照射による酸化を十分に考虑する必 要がある．そのためには放射線酸化の基礎となる照射条 件と酸素の消費量及び発生ガス量との咸係を明らかにす ることが重要である.

照射を受ける高分子試料の形状がフィルムの場合，酸 素の消费噇はフィルムの厚さ，線量率，酸素の圧力に依 存することが報告されている2)。これはフィルム内部の 酸素の㩐度が払散保数, 溶解度係数, 線量率, 及び酸素 王に依存するためであり， $\gamma$ 線照射中の高分子のフィル ム内の酸秦浱度は，フィルム表面から内部に拡散により 供給される量と酸化によって内部で消費される量によっ

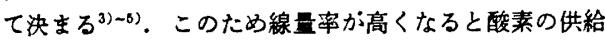
が不足し，酸素の扗散律速によりフィルム内部まで均一 に酸化されなくなる．このような場合には，高分子の劣 化湶量率効果が現れ，酸素の消費量にも見掛け上の線 量率効果が現れる。しかし，更に詳細な研究では，酸素 の抬散の影整が無視しらる条件においてすポリエチレン

*1 日本原子力研究所高绮研究所 (370-12 高崎市綿 貫町 1233)
(PE) とエチレンープロピレン共重合体 (EPR) の酸素の 消费量に線量率効果が見いたされている゙の,7).

高分子の放射線酸化に招いて，酸索の消費量やカルボ ニルの量を調べる研究では, 酸素の拡散が無視しらる形 状の試料 (微粉末や薄膜) を用いて実験されており， $\mathrm{PE}^{(1), 2), 8)}, \mathrm{EPR}^{1), 8)}$, ポリプロピレン(8),(日),10), ポリエチ レンオキサイド11)，及びポリ塩化ビニル122,13) について 報告されている，しかしながら，報告されている酸素の 消費量及び発生ガス量の值は研究者間により線量率や定 每方法が異なっているため必ずしも一致していない. 本 報告は高分子材料を放射線の場で使用したときの使用限 界の推定を目的とした研究の一環として、フィルム状あ るいはシート状の試料を照射した場合に, 試料の厚さと 照射条件によって酸素の消费量がどのような影整を受け るかについて報告する。

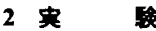

\section{1 酛料}

実験に使用した試料の名称とその物珄値を Table 1 に示す. Sumikathene G804 は沸滕キシレン中で溶解 し，冾却により再結晶化させたものをてセトンで洗浄し た後, 真空稪燥させた. EP-07P は 0.05 phr (Part per hundred regin) の酸化防止剂が入っている. 試料はい ずれあ熱プレスにより均一な厚さのフィルムに成形した が, 各フィルムとも厚さの誤差は $\pm 0.1 \mathrm{~mm}$ 程度であ る.

2.2 照射

各フィルム試料約 $1 \mathrm{~g}$ を切り取り精科した後,ブレー

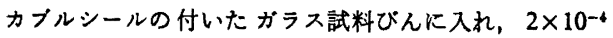


Table 1. Properties of polyethylene and ethylene-propylene copolymer

\begin{tabular}{clccccc}
\hline \hline Polymer & Manufacture & $\begin{array}{c}\text { Density } \\
\left(\mathrm{g} / \mathrm{cm}^{\mathrm{s}}\right)\end{array}$ & $\begin{array}{c}\text { Crystallinity } \\
(\%)\end{array}$ & $\begin{array}{c}\text { Molecular } \\
\text { Weight } \\
M_{n}\end{array}$ & $\begin{array}{c}\text { Mol Fraction } \\
\text { of Ethylene }\end{array}$ \\
\hline I) & $\begin{array}{l}\text { Polyethylene } \\
\text { Sumikathene } \\
\text { G804 }\end{array}$ & $\begin{array}{c}\text { Sumitomo Chemical } \\
\text { Co., Ltd. }\end{array}$ & 0.919 & 43 & $1.7 \times 10^{4}$ & 1.00 \\
$\begin{array}{l}\text { Ethylene-Propylene Copolymer } \\
\text { JSR-EP 07P }\end{array}$ & $\begin{array}{c}\text { Japan Synthetic } \\
\text { Rubber Co., Ltd. }\end{array}$ & 0.86 & 10 & $7.6 \times 10^{4}$ & 0.73 \\
\hline
\end{tabular}

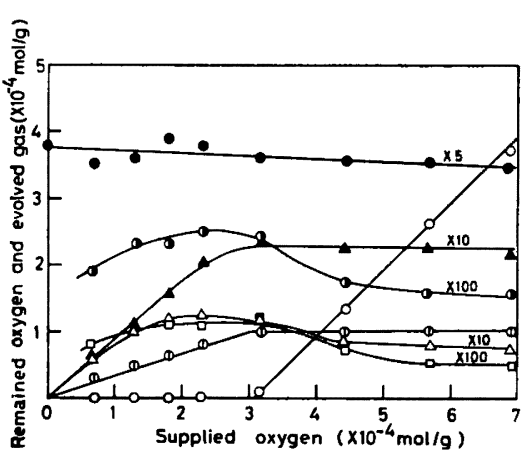

Fig. 1. Remaining oxygen and evolved gases against initially supplied oxygen for polyethylene of $0.2 \mathrm{~mm}$ thickness irradiated in oxygen at a dose rate of $2 \mathrm{kGy} / \mathrm{h}$ up to $214 \mathrm{kGy}$. $\bigcirc \mathrm{O}_{2}$, $\mathbb{1}$. $\mathrm{H}_{2} \mathrm{O}, \bullet \mathrm{H}_{2}, \triangle \mathrm{CO}, \triangle \mathrm{CO}_{2}, \square \mathrm{CH}_{4}$ and $\triangle \mathrm{C}_{2} \mathrm{H}_{6}$.

Paになるまで真空脱気した，真空脱気後，室温で所定 量の酸素ガスを導入してガラス試料びんを熔封した。こ の試料を ${ }^{\circ 0} \mathrm{Co}-r$ 線を用いて $2 \sim 20 \mathrm{kGy} / \mathrm{h}$ の線量率で 室温で照射した。

\section{3 カス分析}

照射により高分子が消費する酸索量と発生がス量を精 度良く定量するためには，ガス圧をより広い範囲で精度 よく測定することが必要であり，本実験では MKS-210 HS-1000 ハラトロン王力計を用いた．ガスの定量分析に は2台のガスクロマトクラフ (GC) を用いた．分析法の 詳細は前報(1),8),14)に記した。

\section{3 結 果}

\subsection{PE}

フィルム状PE を酸素察囲気中で照射した時の酸素の 消費量と発生ガス量を Fig. 1 に示す. Fig. 1 は厚さ $0.2 \mathrm{~mm}$ の試料を酸素印 $4 \times 10^{4} \mathrm{~Pa}$ (300 Torr) で 2 $\mathrm{kGy} / \mathrm{h}$ の線量率で $214 \mathrm{kGy}$ 照射した場合の残存酸来量 と発生ガス量を封入酸亲量に対してプロットしたるのを 示した. 厚さ $0.2 \mathrm{~mm}$ のフィルムの場合, 封入酸素量

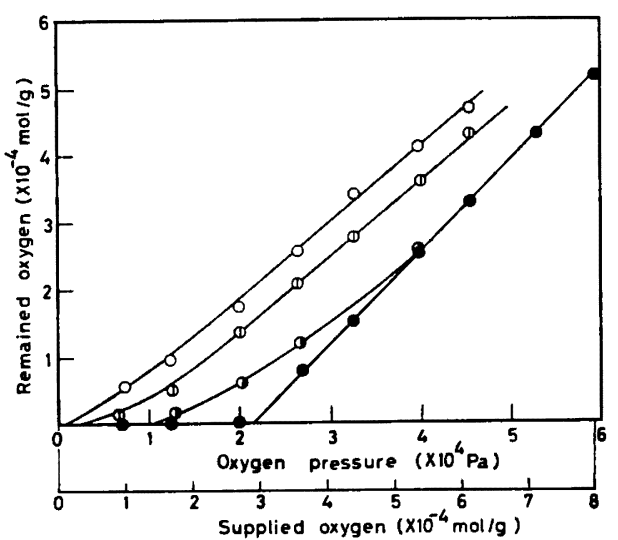

Fig. 2. Relations between remaining oxygen after irradiation and initially supplied oxygen pressure in the sample tube when polyethylene films were irradiated at dose rate of $2 \mathrm{kGy} / \mathrm{h}$ up to $200 \mathrm{kGy}$. Film thickness; $\bigcirc 2.0, \oplus 1.0, \bigcirc 0.5$, and $0.2 \mathrm{~mm}$.

が $3.1 \times 10^{-4} \mathrm{~mol} / \mathrm{g}$ 以下ではすべて消费され，これ以上 の酸素を封入した場合には酸素が残存するようになり， この $3.1 \times 10^{-4} \mathrm{~mol} / \mathrm{g}$ の酸素量がしいい值となってい る.このしきい值は照射線量とPE の種類によっても異 なり ${ }^{1)}$ ，線量の增加とともにより高い酸莱封入睢側に移 動する，GCで検出しらる発生ガスは水索 $\left(\mathbf{H}_{2}\right)$, 二破 化炭素 $\left(\mathrm{CO}_{2}\right)$, 一酸化庆菜 $(\mathrm{CO})$, メタン $\left(\mathrm{CH}_{4}\right)$, 及び エタン $\left(\mathrm{C}_{2} \mathrm{H}_{6}\right)$ である. CO は酸素の封入早とともに生 成量が增加し, 酸菜の封入量が $2.3 \times 10^{-4} \mathrm{~mol} / \mathrm{g}$ 付近て

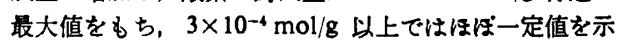
す. 一方, $\mathrm{CO}_{2}$ と $\mathrm{H}_{2} \mathrm{O}$ は封入酸素量が $3.1 \times 10^{-4} \mathrm{~mol} /$ $\mathrm{g}$ 付近まで直線的に增加し，それ以上の封入量では一定 值を示す. $\mathrm{H}_{2}$ はほとんと酸素の影敏を受けていない。

Fig. 2 は $2 \mathrm{kGy} / \mathrm{h}$ の線量率で $200 \mathrm{kGy}$ 照射した時 の酸素の封入王力に対する残存酸素具の成係を示す。

Fig. 2 で明らかなように，同一線量を照射してす試料 が厚くなるはど酸策の消费目は減少しており，また試料 が厚い鹊合封入量と残存量は酸妻の封入匟力によって異 


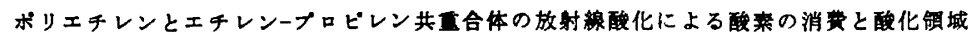

Table 2. G values of Sumikathene $\mathbf{G} 804$ films having different thicknesses irradiated at dose rate $2 \mathrm{kGy} / \mathrm{h}$

\begin{tabular}{|c|c|c|c|c|c|c|}
\hline \multirow{3}{*}{$\frac{\begin{array}{c}\text { Gas } \\
\text { Component }\end{array}}{G\left(-\mathrm{O}_{2}\right)}$} & \multirow{3}{*}{$\frac{0.2}{14.0}$} & \multicolumn{4}{|c|}{ Film thickness (mm) } & \multirow[b]{2}{*}{2.0} \\
\hline & & 0.5 & & & & \\
\hline & & 14.0 & 6. $1^{4)}$ & 8.9 & $3.8^{\mathrm{a})}$ & 6.0 \\
\hline $\boldsymbol{G}\left(\mathbf{H}_{\mathbf{2}}\right)$ & 3.3 & 3.2 & & 3.2 & & 3.3 \\
\hline$G\left(\mathrm{CO}_{2}\right)$ & 1.3 & 1.3 & & $6.0>$ & & $4.3 \times 10^{-1}$ \\
\hline$G(\mathrm{CO})$ & $6.2 \times 10^{-1}$ & $4.8 \times 10^{-1}$ & & $3.4>$ & & $1.7 \times 10^{-1}$ \\
\hline$G\left(\mathrm{C}_{2} \mathrm{H}_{6}\right)$ & $1.2 \times 10^{-1}$ & $1.1 \times 10^{-1}$ & & 3.8 & & $6.0 \times 10^{-8}$ \\
\hline$G\left(\mathrm{CH}_{4}\right)$ & $5.8 \times 10^{-2}$ & $5.7 \times 10^{-8}$ & & $9.1>$ & & $2.2 \times 10^{-2}$ \\
\hline
\end{tabular}

s) Dose rate; $10 \mathrm{kGy} / \mathrm{h}$.

なっている. 厚さ $0.5 \mathrm{~mm}$ の試料は $4 \times 10^{4} \mathrm{~Pa}$ 以上の 酸素任力で厚さ $0.2 \mathrm{~mm}$ の試料とよく一政し, 試料の 厚さの影籍がなくなっている.このことは厚さ $0.5 \mathrm{~mm}$ の試料を $2 \mathrm{kGy} / \mathrm{h}$ の線量率で照射した場合 $4 \times 10^{4} \mathrm{~Pa}$ 以上の酸素圧力であれば，試料の内部まで完全に酸化さ れることを示している. 試料の厚さを変えた場合の酸素 の消費の $G$ 值 $\left[G\left(-O_{2}\right)\right]$ を Table 2 に示す. 厚さ 1.0 及び $2.0 \mathrm{~mm}$ の試料の $\boldsymbol{G}\left(-\mathbf{O}_{2}\right)$ 值は酸素王力が $4 \times$ 104 Pa (300 Torr) の実雊点から求めた值を示した. Table 2 において，同一厚さの試料です線量率が高くな ると $\boldsymbol{G}\left(-\mathrm{O}_{2}\right)$ 值は小さくなっている.このことは線量 率か高くなることにより酸素の消费速度がよりさくな り，酸素の拆散が律速となりフィルム内部で酸化されな い領域が增加していることを示している.

\subsection{EPR}

Fig. 3 に厚さ $1.0 \mathrm{~mm}$ の試料を用い，酸素の封入匤力 を変えた場合の残存酸素量について $2,10 \mathrm{kGy} / \mathrm{h}$ ，及び $20 \mathrm{kGy} / \mathrm{h}$ の線量害で $200 \mathrm{kGy}$ 照射した結果について示 す. $20 \mathrm{kGy} / \mathrm{h}$ の線量率の場合， $2.5 \times 10^{4} \mathrm{~Pa}$ 以下の封 入酸素仕力では酸素の消费量が封入酸素仕力によって変 化している. 同様に $10 \mathrm{kGy} / \mathrm{h}$ の線量率です $1.8 \times 10^{4}$ $\mathrm{Pa}$ 以下の封入王力で恃酸素の消费量に王力依存性が現 れている. $2 \mathrm{kGy} / \mathrm{h}$ の線是率で照射した場合は封入酸素 王力がかなり低い場合であ仕力依存性が現れなくなり， $1.3 \times 10^{4} \mathrm{~Pa}$ (100 Torr) の王力でも酸素の消费量に圧力 依存性が現れていない：このことは厚さ $1.0 \mathrm{~mm}$ の試 料でも $2 \mathrm{kGy} / \mathrm{h}$ の線量率であれば $1.3 \times 10^{4} \mathrm{~Pa}$ 程度の 王力です試料の内部まで完全に酸化されていることを示 している. Fig. 3 の結果から, 厚さ $1.0 \mathrm{~mm}$ の試料を 用いた場合, $20 \mathrm{kGy} / \mathrm{h}$ の線量率です $2.5 \times 10^{4} \mathrm{~Pa}$ 以上 の酸素圧力であれば酸素の消費量に圧力依存性を示さな いことから，酸素圧力を $6.7 \times 10^{4} \mathrm{~Pa}$ (500 Torr) にし た場合の封入酸素量と残存量の咸㐿を調へた。 その結果 をFig. 4 に示す. Fig. 4 は2,10kGy/h，及び 20 $\mathrm{kGy} / \mathrm{h}$ の各線量率で $200 \mathrm{kGy}$ 照射した場合について示 したもので，いずれも酸素の封入量に対し残存量は $1: 1$

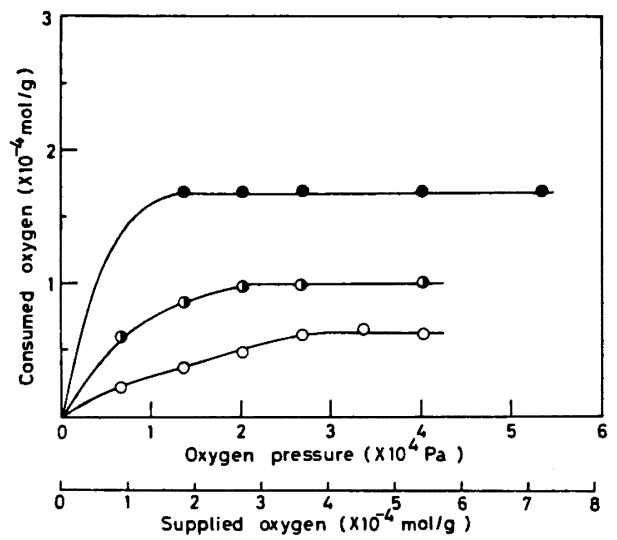

Fig. 3. Relations between consumed oxygen after irradiation and initially supplied oxygen pressure in the sample tube when ethylene propylene copolymer of $1.0 \mathrm{~mm}$ thickness were irradiated with different dose rates up to $200 \mathrm{kGy}$. Dose rate; $O 20 \mathrm{kGy} / \mathrm{h}, 10 \mathrm{kGy} / \mathrm{h}$, and 2 $\mathrm{kGy} / \mathrm{h}$.

の関係にあり，したがって Fig. 4 では $45^{\circ}$ の勾配を すつ直線烕係を示している. Fig. 5 は線貫率と酸菜の 封入圧力を一定として, 試料の厚さを変えた場合の結果 について示したすので, 線量率は $2 \mathrm{kGy} / \mathrm{h}$, 酸素の封入 圧力は $6.7 \times 10^{4} \mathrm{~Pa}$ である. 試料の厚さが $0.5,1.0$, 及び $2.0 \mathrm{~mm}$ のいずれの場合も $200 \mathrm{kGy}$ 照射した時の 酸素の消費量か同じであり，この照射条件では試料の厚 さの効果が現れない，線量率を変えた埸合の $G\left(-\mathrm{O}_{2}\right)$ 値と発生ガスの $G$ 值を Table 3 に示した.

\section{4 考案}

Table 2 で示したよらに, 同一線量率・線量において も試料の厚さが異なると酸素の払散律速により, 酸素の 消費量は異なる.ここで次のような放射線酸化反応によ 


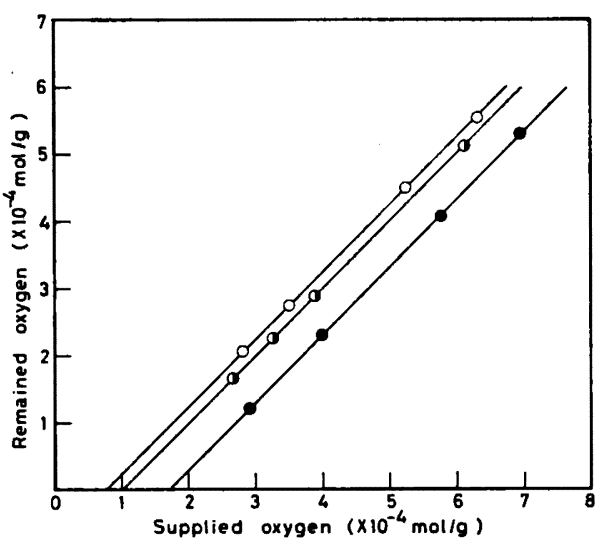

Fig. 4. Relations between remaining oxygen after irradiation and initially supplied oxygen (constant pressure; $6.65 \times 10^{4} \mathrm{~Pa}$ ) in the sample tube when ethylene-propylene copolymer of $1.0 \mathrm{~mm}$ thickness irradiated with different dose rates up to $200 \mathrm{kGy}$. Dose rate; $020 \mathrm{kGy} / \mathrm{h}, D 10 \mathrm{kGy} / \mathrm{h}$, and $\odot 2 \mathrm{kGy} / \mathrm{h}$.

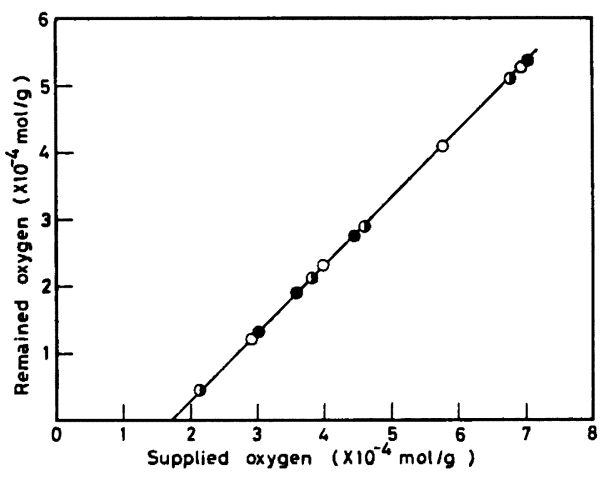

Fig. 5. Relations between remaining oxygen after irradiation at dose rate of $2 \mathrm{kGy} / \mathrm{h}$ up to $200 \mathrm{kGy}$ and initially supplied oxygen (constant pressure; $6.65 \times 10^{4} \mathrm{~Pa}$ ) for ethylene-propylene copolymer. Sample thickness; $0.5 \mathrm{~mm}, \bigcirc 1.0 \mathrm{~mm}$, and $2.0 \mathrm{~mm}$.

り酸素が消费されると仮定する。

$$
\begin{aligned}
& \text { ラジカル生成反応 } \\
& \mathbf{M} \sim \stackrel{\phi I}{\longrightarrow} \mathbf{M} \text {. } \\
& \phi I \\
& \mathrm{M} \cdot+\mathrm{M} \cdot \stackrel{k_{1}}{\longrightarrow} \mathrm{M}-\mathrm{M} \quad k_{1}[\mathrm{M} \cdot]^{2} \\
& \mathrm{M} \cdot+\mathrm{O}_{2} \stackrel{k_{2}}{\longrightarrow} \mathrm{M}-\mathrm{O}_{2} \quad k_{2}[\mathrm{M} \cdot]\left[\mathrm{O}_{2}\right]
\end{aligned}
$$

Table 3. Effect of dose rate of EP-07P film on the $G$ values with irradiation (film thickness; 1 $\mathrm{mm}$, oxygen pressure; $\left.6.65 \times 10^{4} \mathrm{~Pa}\right)$

\begin{tabular}{llll}
\hline \multirow{2}{*}{ Gas Compn. } & \multicolumn{3}{c}{$G$ value } \\
\cline { 2 - 4 } & $2 \mathrm{kGy} / \mathrm{h}$ & $10 \mathrm{kGy} / \mathrm{h}$ & $20 \mathrm{kGy} / \mathrm{h}$ \\
\hline$G\left(-\mathrm{O}_{2}\right)^{\mathrm{a})}$ & 8.0 & 4.9 & 3.9 \\
$G\left(\mathrm{H}_{2}\right)$ & 3.5 & 3.6 & 3.6 \\
$G\left(\mathrm{CO}_{2}\right)$ & $5.9 \times 10^{-1}$ & $5.5 \times 10^{-1}$ & $4.5 \times 10^{-1}$ \\
$G(\mathrm{CO})$ & $1.2 \times 10^{-1}$ & $1.3 \times 10^{-1}$ & $1.3 \times 10^{-1}$ \\
$G\left(\mathrm{CH}_{4}\right)$ & $3.8 \times 10^{-2}$ & $3.8 \times 10^{-2}$ & $3.8 \times 10^{-2}$ \\
$G\left(\mathrm{H}_{2} \mathrm{O}\right)$ & 2.1 & 1.3 & 1.0 \\
\hline
\end{tabular}

a) Oxygen Consumption.

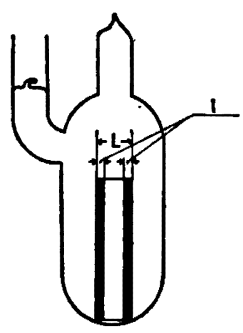

Fig. 6. Schematic diagram for the sample tube and oxidation region in the cross section of polymer film irradiated in oxygen atmosphere. L; Film thickness $(\mathrm{cm}), l$; Oxidation layer $(\mathrm{cm})$.

ここで M, M. は高分子鎖及び高分子鎖に生成した ラジカルを表し，〔はラジカルの生成速度定数，Iは線 量率 $(\mathrm{Gy} / \mathrm{h}) ， k_{1}, k_{2}$ 汳反应速度定数である. Fig. 6 K 示したような厚さ $L(\mathrm{~cm})$ のフィルム状試料が放射線照 射により酸化される厚さ $l(\mathrm{~cm})$ は次式で示される゙．

$$
l=\sqrt{\left(1-\frac{2}{k_{2} C_{0}} \cdot \sqrt{\left.\frac{k_{1} \phi I}{\varepsilon}\right) \cdot \frac{2 D C_{0}}{\psi I}}\right.}
$$

ここでDは酸素の陚料内への抬散係数 $\left(\mathrm{cm}^{2} / \mathrm{s}\right), C_{0}$ は 陚料表面における溶解度 $(\mathrm{mol} / \mathrm{g}), \varepsilon$ は $0<\varepsilon<1$ の籍囲 の数である. 試料表面の酸㕖圧力を $P(\mathrm{~atm})$ とし，溶解 度俰数を $S(\mathrm{~mol} / \mathrm{g} \cdot \mathrm{atm})$ とすると，C $C_{0}=S P$ である。 $k_{2} \ll k_{1}$ でない場合 $1-\left(2 / k_{2} C_{0}\right) \sqrt{k_{1} \psi I / \varepsilon}=1$ と近似され, (4) 式は次式のよ5になる

$$
l=\sqrt{\frac{2 D C_{0}^{-}}{\psi I}}=\sqrt{\frac{2 D S}{\psi} \cdot \frac{P}{I}}
$$

Fig. 6 で示したよらな陚料びんの容積 $V\left(\mathrm{~cm}^{3}\right)$ の中に, 酸素ガスを $P_{0}(\mathrm{~atm})$ の圧力で封入した時の酸素具は $P_{0} V=n_{0} R T$ であるから, 線量率 $I$ で照射した场合の時 间 $t(\mathrm{~s})$ 後の試料びん内の酸㭉 $n_{\mathrm{t}} \mathrm{mol}(P \mathrm{~atm})$ は, $L$ $>2 l$ の条件で

$$
n_{\mathrm{t}}=\frac{P_{\mathrm{t}} V}{R T}=n_{0}-\int_{0}^{t} \psi I \cdot \frac{2 l}{L} \cdot W \mathrm{~d} t
$$




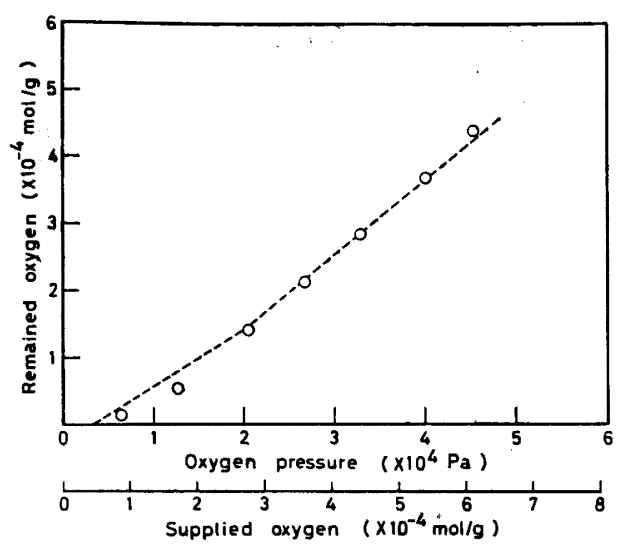

Fig. 7. Relation between remaining oxygen after irradiation and initially supplied oxygen in the sample tube when polyethylene films were irradiated up to $200 \mathrm{kGy}$. O Observed (film thickness $1.0 \mathrm{~mm}$ at a dose rate of $10 \mathrm{kGy} / \mathrm{h}), \ldots$ calculated from eq. (7).

Table 4. Oxidation layer thickness of polyethylene sheet irradiated at dose rate of $2 \mathrm{kGy} / \mathrm{h}$ and $10 \mathrm{kGy} / \mathrm{h}$ with different oxygen pressure at room temperature

\begin{tabular}{rlllll}
\hline \hline \multirow{2}{*}{$\begin{array}{c}\text { Oxygen } \\
(\mathrm{Pa})\end{array}$} & $\begin{array}{c}\text { Pressure } \\
(\mathrm{atm})\end{array}$ & $\begin{array}{c}\text { Solubility } \\
C\left(\times 10^{-8}\right. \\
\text { mol } / \mathrm{g})\end{array}$ & \multicolumn{2}{c}{$\begin{array}{c}\text { Oxidation Layer } \\
(\mathrm{cm})\end{array}$} \\
\hline 1333 & $\mathbf{0 . 0 1 3 2}$ & $\mathbf{0 . 0 2 9 0}$ & $\mathbf{0 . 0 0 3 8}$ & $\mathbf{0 . 0 0 6 5}$ \\
13332 & $\mathbf{0 . 1 3 2}$ & 0.290 & 0.0119 & 0.0204 \\
26664 & 0.263 & 0.579 & 0.0159 & 0.0279 \\
39996 & 0.395 & 0.869 & 0.0207 & 0.0354 \\
53328 & 0.526 & 1.157 & 0.0239 & 0.0408 \\
66660 & 0.658 & 1.448 & 0.0267 & 0.0456 \\
79992 & 0.789 & 1.736 & 0.0292 & 0.0500 \\
93324 & 0.921 & 2.026 & 0.0297 & 0.0521 \\
\hline
\end{tabular}

である.ここで $W$ は試料の重量（g）を示し，Wを $1 \mathrm{~g}$ とすると,

$$
n_{\mathrm{t}}=\frac{P_{\mathrm{t}} V}{R T}=n_{0}-\frac{2 \sqrt{2 \cdot \phi I D S_{0}}}{L} \int_{0}^{t} \sqrt{ } P \mathrm{~d} t
$$

となる.

Sumikathene G804 の場合, 払散係数 $D$ は $5.6 \times$ $10^{-7} \mathrm{~cm}^{2} / \mathrm{s}^{16), 18)}$, 溶解度係数 $S$ は $2.2 \times 10^{-6} \mathrm{~mol} / \mathrm{g}$. $\mathrm{atm}^{16), 18)}$ であり，2 kGy/h の線量率で照射した場合の 酸素の消費の $G$ 値は 14.0 であるから， $\phi$ は $1.5 \times$ $10^{-13} \mathrm{~mol} / \mathrm{g} \cdot \mathrm{Gy}$ である.これらの值と (7) 式を用いて， Sumikathene G804 の厚さ $1.0 \mathrm{~mm}$ のフィルム状試料 を $10 \mathrm{kGy} / \mathrm{h}$ の線量率で $200 \mathrm{kGy}$ 照射した時の封入酸
Table 5. Oxidation layer thickness of ethylenepropylene copolymer sheet irradiated at dose rate of $2 \mathrm{kGy} / \mathrm{h}$ and $10 \mathrm{kGy} / \mathrm{h}$ with different oxygen pressure at room temperature

\begin{tabular}{rlccc}
\hline $\begin{array}{c}\text { Oxygen } \\
(\mathrm{Pa})\end{array}$ & $\begin{array}{c}\text { Pressure } \\
\text { (atm) }\end{array}$ & $\begin{array}{c}\text { Solubility } \\
\mathrm{C}\left(\times 10^{-\theta}\right. \\
\mathrm{mol} / \mathrm{g})\end{array}$ & \multicolumn{2}{c}{$\begin{array}{c}\text { Oxidation Layer } \\
(\mathrm{cm})\end{array}$} \\
\hline 1333 & 0.0132 & 0.0634 & 0.0113 & 0.0192 \\
13332 & 0.132 & 0.634 & 0.0356 & 0.0608 \\
26664 & 0.263 & 1.262 & 0.0503 & 0.0901 \\
39996 & 0.395 & 1.896 & 0.0616 & 0.105 \\
53328 & 0.526 & 2.525 & 0.0711 & 0.121 \\
66660 & 0.658 & 3.158 & 0.0796 & 0.136 \\
79992 & 0.789 & 3.787 & 0.0871 & 0.149 \\
93324 & 0.921 & 4.421 & 0.0941 & 0.169 \\
\hline
\end{tabular}

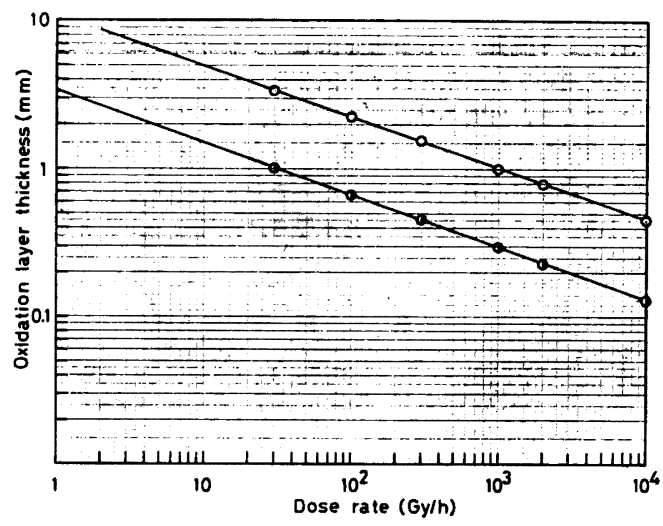

Fig. 8. Oxidation layer thickness of polyethylene and ethylene-propylene copolymer film irradiated in oxygen of $0.21 \mathrm{~atm}\left(2.13 \times 10^{4} \mathrm{~Pa}\right)$ with different dose rates at room temperature. O EP 07P, Sumikathene G804.

秦代力と残存酸素量を計算により求めた結果を Fig. 7 に示した，計算値と実験値はよく一致している，一方， フィルム状試料が放射線照射により酸化される厚さ $l$ は (5) 式により計算で求めることができる.ここでは Sumikathene G804 と EP-07P のフィルム状試料を 2 $\mathrm{kGy} / \mathrm{h}$ 及び $10 \mathrm{kGy} / \mathrm{h}$ の線量率で照射した場合の酸素 の圧力に対して酸化されらる厚さを計算した. Table 4 に Sumikathene G804 を, Table 5 に EP-07P につ いて示した. Table 4 において，例えば線量率が 2 $\mathrm{kGy} / \mathrm{h}$ で試料の厚さが $1 \mathrm{~mm}$ の場合, 酸素の王力が $8.0 \times 10^{4} \mathrm{~Pa}$ 以下では試料の内部まで均一に酸化されな いことが分かる. したがって，このような条件では酸素 の消費量を正確に求めることができない，空気中照射 
(酸来の分圧 $2.1 \times 10^{4} \mathrm{~Pa}$ ) した场 合に, Sumikathene G804 と EP-07P が酸化される原さと線量率の夙係は各 線量率における酸亲の消费量が明らかとなっていれば (5) 式から計算により求めることができ，その結果を Fig. 8 に示す. Fig. 8 から明らかなよらに，低線典率 ほど酸化される厚さが增大し，酸化される厚さは線量率 に対し $-1 / 3$ 乗を示している.この酸化される厚さが線 舞に対し $-1 / 3$ 乗を示す原因は，著者らか既に報告? したように Sumikathene G804 と EP-07P の酸素の消 费の $\boldsymbol{G}$ 値が線量率に対し $-1 / 3$ 乗の依存性を示すこと から説明しらる．また(5) 式から，酸桑の消費量に線量 率依存性がない場合の酸化される厚さは線量率に対し -1/2 乗であることが予測しらる.

\section{5 結战}

ポリエチレンとェチレンープロピレン共重合体の $\gamma$ 線 照射による酸秦の消费量とガス哞生量をガスクロマトク ラフを用いて調べた. 酸素の消费量はフィルム状試料が 厚くなると，酸萃の扗散律速により，隇少する，この酸 素の消费量は払散モテルを用いて計算した値と実験値か よく一致した. ポリェチレンとェチレンープロピレン共 重合体のフィルムの酸化される厚さは線量の $-1 / 3$ 乗に 比例する.

\section{文献}

1) K. Arakawa, T. Seguchi, Y. Watanabe, and N. Hayakawa, J. Polym. Sci., Polym. Chem. Ed., 20, 2681 (1982).

2) H. Matsuo and M. Dole, J. Phys. Chem., 63, 837 (1959).

3) R. C. Giberson, J. Phys. Chem., 66, 463 (1962).
4) R. C. Giberson, J. Polym. Sci., A, 2, 4965 (1964).

5) T. Seguchi, S. Hashimoto, Y. Kawakami, and I. Kuriyama, Japan Atomic Energy Research Institute Report, JAERI-M 7315 (1977).

6) C. Decker, F. R. Mayo, and H. Rechardson, J. Polym. Sci., Polym. Chem. Ed., 11, 2879 (1973).

7) K. Arakawa, T. Seguchi, Y. Watanabe, N. Hayakawa, I. Kuriyama, and S. Machi, $J$. Polym. Sci., Polym. Chem. Ed., 19, 2123 (1981).

8) C. Decker and F. R. Mayo, J. Polym. Sci., Polym. Chem. Ed., 14, 1513 (1976).

9) E. A. Hegazy, T. Seguchi, K. Arakawa, and S. Machi, J. Appl. Polym. Sci., 26, 1361 (1981).

10) W. Schnabel and M. Dole, J. Polym. Chem., 70, 883 (1966).

11) C. Decker, J. Polym. Sci., Polym. Chem. Ed., 15, 799 (1977).

12) C. Decker, J. Appl. Polym. Sci., 20, 3321 (1976).

13) E. A. Hegazy, T. Seguchi, and S. Machi, J. Appl. Polym. Sci., 26, 2947 (1981).

14) K. Arakawa, T. Seguchi, N. Hayakawa, and S. Machi, J. Polym. Sci., Polym. Chem. Ed., 21, 1173 (1983).

15) T. Seguchi, S. Hashimoto, K. Arakawa, N. Hayakawa, W. Kawakami, and I. Kuriyama, Radiat. Phys. Chem., 17, 195 (1981).

16) T. Seguchi and K. Arakawa, Japan Atomic Energy Research Institute Report, JAERI-M 9671 (1981).

Oxygen Consumption and Oxidation Region by Radiation-Induced Oxidation in Polyethylene and EthylenePropylene Copolymer

Kazuo Arakawa*1 and Tadao Seguchi*1

*1Japan Atomic Energy Research Institute, Takasaki Radiation Chemistry Research Establishment (1233, Watanuki-Machi, Takasaki, 370-12 Japan)

Oxygen consumption and yield of oxidation products during $r$-irradiation are studied on polyethylene (PE), and ethylene-propylene copolymer (EPR) using a gas chromatography. Polymer films of different thickness are irradiated in oxygen by ${ }^{\circ 0} \mathrm{Co} \gamma$-rays up to $200 \mathrm{kGy}$ with a dose rate (I) of $2 \mathrm{kGy} / \mathrm{h}-20 \mathrm{kGy} / \mathrm{h}$ at room temperature. The $G$-values of oxygen consumption decrease with film thickness and with dose rate, showing that oxidation is controlled by diffusion of oxygen. The amount of oxygen consumption is in excellent agreement with the values calculated by using a diffusion control model. Oxidation layer thickness of PE and EPR film is apparently proportional to $I^{-1 / 8}$.

KEY WORDS Polyethylene / Ethylene-Propylene Copolymer / Oxygen Consumption / Oxidation Layer Thickness / Gamma-Rays / G-Value / Evolved Gas /

(Received April 27, 1984: Accepted July 14, 1984)

[Kobunshi Ronbunshu, 41 (12), 733-738 (1984)] 